\title{
Effects of 6.5 and 17.5 Hour Milking Intervals on the Yield and Udder Health in Dairy Cows
}

\author{
Tadao ICHIKawa* and Tohru Fujishima** \\ *Agricultural and Forestry Research Center, the University \\ of Tsukuba, Sakura-mura, Ibaraki 305 \\ ${ }^{* *}$ National Institute of Genetics, Mishima-shi, 411
}

(Received November 11, 1981)

It has been conventional for a long time that milking at 12 -hour intervals be carried out for highest production from dairy cows, when a twice daily milking schedule is employed. Recent increases in wages, however, have required milking to be done within the eight hours of working day without premium payment for overtime work: this has led to unequal intervals between milkings.

Many researchers have found that cows milked at unequal intervals yield less milk than those milked at equal intervals, though only a few ${ }^{1-4)}$ of them have confirmed the significant difference in milk production between those two milking routines. Milking intervals during the daytime employed in previous experiments were more than 8 hours, most of them being between $8.5 \sim 9.0$ hours. Our previous experiments ${ }^{4}$, in which milking intervals were 7.5 and 16.5 hours, revealed a significant decrease of $2.4 \%$ in milk production and in milk composition, except for fat production due to unequal interval milkings, although no adverse effect was detected in udder health.

With increasing herd sizes, however, it has become difficult to complete a twice daily milking routine within 8 or 9 hours during the daytime even if such unequal intervals as in our experiment were practised. In the present study, therefore, further investigation of a more severe difference between milking intervals, $6.5 \sim 17.5 \mathrm{hrs}$, was conducted to confirm the effects of unequal interval milking upon the production and udder health of dairy cows. An economic evaluation of unequal interval milking was also discussed.

\section{Materials and Methods}

Fourteen Holstein cows producing a daily average of $25.8 \mathrm{~kg}$ milk (range $19 \sim 33$ $\mathrm{kg}$ ) were used for the present experiment, in which a five period double switch-back experiment was employed, with each experimental period consisting of 3 weeks. Millking intervals were $6.5 \sim 17.5 \mathrm{hrs}$. for the unequal interval milkings and $11.5 \sim 12.5 \mathrm{hrs}$.

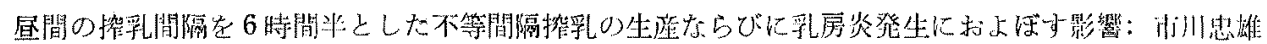

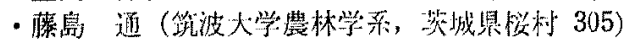

Jpn. J. Zootech. Sci., 53 (5): 355-358 
for the control. Each cow was individually fed according to the Japanese Feeding Standard for Dairy Cattle; $15 \mathrm{~kg}$ of grass silage, $5 \mathrm{~kg}$ of alfalfa-hay cube, $3 \mathrm{~kg}$ of timothy hay, $2 \mathrm{~kg}$ of beet-pulp and concentrate mixture at the rate of $1 \mathrm{~kg}$ per $3 \mathrm{~kg}$ milk were given daily throughout the experiment. Milk yields were recorded at each milking time, and milk fat and solid not fat (SNF) content of A.M. and P. M. milk were determined once a week. The modified California Mastitis Test (CMT) and the Wisconsin Mastitis Test (WMT) were also applied weekly for quarter milk samples to examine the effects of unequal interval milking on the udder health of cows. Statistical analysis of the data was done according to the modified analysis of the twotreatment switchback design described by FuJISHIMA and ICHIKAWA ${ }^{5)}$.

\section{Results and Discussion}

The average daily milk yields were $22.02 \mathrm{~kg}$ for the unequal interval milking period and $22.55 \mathrm{~kg}$ for the control period, respectively. The difference of $0.53 \mathrm{~kg}$ between the two periods, meant a $2.4 \%$ decrease in the unequal interval period compared to the control period, this value being almost the same as that of our previous finding(4). It was also statistically significant at a $5 \%$ level of probability.

Although many researchers have observed a decrease in milk yield in unequal interval milking compared to equal interval milking, it should be noted that the extent of the decrease was confined within a range from 2 to 3 percent in most cases, in spite of the fact that the milking intervals and productivity of cows employed in their experiments were different.

No difference was found in the percentage of both milk fat and SNF between the unequal interval milking period and the control period, in the present study. However, the yield of SNF decreased significantly in the unequal interval milking period compared with the control period by $2.5 \%$, which was nearly equivalent in value to the decrease in milk yield. Although the percentage of SNF was not affected by

Table 1. Daily yields of milk and milk constituents, percentage of the constituents, and indicators of mastitis during experimental periods.

\begin{tabular}{lccccc}
\hline & & $\begin{array}{c}6.5-17.5 \mathrm{hrs} \\
\text { milking interval } \\
\text { period (T) }\end{array}$ & $\begin{array}{c}11.5-12.5 \mathrm{hrs} \\
\text { milking interval } \\
\text { period (C) }\end{array}$ & $\begin{array}{c}\text { Differences } \\
(\mathrm{T}-\mathrm{C})\end{array}$ & $\begin{array}{c}\text { Reduction from } \\
\text { control interval } \\
(\%)\end{array}$ \\
\hline Milk yield & $\mathrm{kg}$ & 22.02 & 22.55 & $-0.53^{* *}$ & 2.4 \\
Milk fat yield & $\mathrm{kg}$ & 0.804 & 0.822 & -0.017 & 2.1 \\
Milk fat content & $\%$ & 3.70 & 3.68 & 0.02 & -0.5 \\
SNF yield & $\mathrm{kg}$ & 1.973 & 2.024 & $-0.051^{* *}$ & 2.5 \\
SNF content & $\%$ & 8.99 & 9.01 & -0.02 & 0.2 \\
CMT score & & 0.201 & 0.331 & -0.13 & 39.3 \\
WMT value & 14.20 & 15.68 & -1.48 & 9.4 \\
\hline
\end{tabular}

1) Significance tests were done according to the procedure proposed by Fujishima and Ichikawa, and a **mark means significance at 0.01 level of probability. 2) CMT score were given according to the grade of gel-forming reaction of CMT as follows; $( \pm) \cdots 1,(+) \cdots 2$, $(+) \cdots 3,(H) \cdots 4$. 
unequal interval milking, the decrease in milk yield resulted in depressing the SNF yield. This is in agreement with the finding of Ormiston et al. ${ }^{6)}$ who concluded that the distribution of SNF percentage between A. M. and P. M. milking was not affected by the milking intervals, but that milk fat percentage obtained after a long interval was lower than that following a short interval. The proportion of morning milk yield to the daily milk yield was $71 \%$ for the unequal interval milking period and $56 \%$ for the control period, both of which corresponded very well to that of the expected milk yield based on the length of milking interval as described in our previous report.

The CMT score and WMT value for the unequal interval milking period were both less than those for the control period, although an adverse tendency was observed in our previous experiment. If mastitis is defined as a quarter which has more than a \# grade of gel-forming reaction of CMT, the percentage of mastitis quarters in cows employed at the beginning of the experiment was $9.7 \%$ for the previous and $8.9 \%$ for the present experiment. A combined judgement based on present and previous results suggests that the unequal interval milking would not have any adverse effects on udder health. However, there is no evidence to show whether or not a herd which has a more serious mastitis problem could remain unaffected by such severe milking intervals.

Since the extent of decrease in milk yield was the same in both of our experiments, the relationship between the productivity of individual cows and the decrease in milk yield in the unequal interval milking period was examined together with 14 samples of the previous and 31 samples of the present experiment. A regression equation of a cow's production $(X)$ on the decrease in milk yield $(X)$ was " $Y=0.387$ $0.030 X "(n=45)$. Although the regression coefficient was negative, non significance was found in the above equation. Thus, the common belief that high yielding cows would suffer more from an unequal milking interval than lower yielding cows is not verified by the present analysis. This is in agreement with the conclusion drawn by Schmidt and Trimberger ${ }^{7}$, and other researchers ${ }^{2,16)}$.

If equal interval milking is practised, overtime payment must be disbursed in dairy farms such as National Institutions, Public Stations and large scale farms where labour mainly depends on employees rather than farming family members. A trial evaluation of the profit-and-loss account for an unequal interval milking system was made from an economic point of view. The relationship between the amount of overtime payment and decrease in income due to the adoption of an unequal interval milking routine was estimated. The calculation based on the following four items was made for various herd sizes: (1) The reduction in milk yield due to unequal interval milking was estimated at $0.6 \mathrm{~kg} / \mathrm{head} /$ day according to our previous and present results. (2) The milk sale price was taken to be 100 yen per $1 \mathrm{~kg}$, supposing $3.2 \%$ fat. (3) The average amount of overtime payment for government employees in Japan is now 1,370 yen per hour. (4) The average amount of payment for temporary employees in agriculture was 5, 047 yen per day ${ }^{8}$. 
The result showed that economic advantage would be gained in the case of unequal interval milking in dairy farms with more than 17 milking cows, depending on the labour of government employees. The use of temporary labour might appear to be one way of avoiding greater economic loss, but it should be noted that it is practically impossible to hire temporary workers in dairy farming in Japan.

Because our results were not obtained from a complete lactation record but from a short period of switch-back experiment, more practical experiments covering complete lactation will require to be conducted to ascertain the effects when such unequal interval milking is employed as routine work in dairy farming.

This experiment was carried out at the Shizuoka Prefectural Livestock Experimental Station when the senior author was there. Thanks are due to the staffmembers of the station for their kind cooperation.

\section{References}

1) Spahr, S. L. and E. E. Ormiston, J. Dairy Sci., 49: 729. 1966.

2) Balika, S., Dairy Sci Abstr 35: 108 p. 1973.

3) Hansson, A., O. Claesson, E. Brannang, and N. Gustafsion, Acta Agt Scand 8: 296-318. 1958.

4) Ichikawa, T. and T. Fujishima, Jpn. J. Zootech. Sci., 47: 518-525. 1976.

5) Fujishima, T. and T. Ichikawa, Jpn. J. Zootech. Sci., 47: 68-72. 1976.

6) Ormiston, E. E., S. L. Spahr, R. W. Touchberry and J.L. Albright, J. Dairy Sci., 50: 15971605. 1967.

7) Schmidr, G. H. and G. W. Trimberger, J. Dairy Sci., 46: 19-21. 1963.

8) Statistics and Information Department, Ministry of Agriculture, Forestry and Fisheries, Statistics on Prices and Wages in Rural Areas, F. Y. 1978: 220. 1979. 